\title{
COVID-19 AS A PUBLIC HEALTH PROBLEM IN NIGERIA: A SOCIOPRAGMATIC READING OF HEALTH ISSUES IN JENIFA ON LOCKDOWN
}

\author{
Olafenwa BR*
}

\author{
Department of English, Faculty of Arts, Obafemi Awolowo University, Ile-Ife, Nigeria
}

\begin{abstract}
This study examines COVID-19 as a public health problem in Nigeria as reflected in health issues raised about the disease in a SceneOne TV YouTube channel drama series Jenifa on Lockdown. The drama showcases the Nigerian experience of the first wave of COVID-19 in 2020. This study does a socio-pragmatic reading of highlighted health concerns from a stylistic perspective. It seeks to validate the applicability of utterances of characters to the establishment of the realness of COVID-19 and corruption as the bane of preventive and control measures in Nigeria. This research adopted a qualitative approach. It employed John Searles' model of Speech Act Theory as its theoretical framework. Relevant illocutionary acts were collected from selected episodes of the satirical performance as data. The paper reveals that COVID-19 is a major public health problem in Nigeria. It identifies political corruption, especially the embezzlement of budgetary allocation to health as a factor that undermines the implementation of a desired high-level strategic response to the disease. It distinguishes health challenges such as underfunding and understaffing of the health sector, alarming population per health center, lack of isolation centers, non-remuneration of frontline health workers, unethical practices among health workers, and the discouragement of volunteerism as consequences. It concludes that ridding Nigeria of corruption is necessary to solve identified health challenges and improve its health care system. It recommends a bottom-top approach that entails social accountability to achieve answerability, good governance, a successful and sustainable health system in Nigeria. This research endorses the effectiveness of dramatic campaigns on social media in health promotion. It establishes the efficiency of the approach to health care and wellbeing, using insights from dramatic performance, stylistics, and pragmatics. Thus, it suggests further linguistic research into critical, dramatic perceptions of health to boost healthcare and wellbeing.
\end{abstract}

Keywords: public health, COVID-19, Nigeria, corruption, social media, dramatic performance

\section{Introduction}

\section{Background}

The coronavirus disease 2019 (COVID-19) is a highly contagious virus caused by the novel severe acute respiratory syndrome coronavirus 2 (SARS-CoV-2) (Ogbolosingha and Singh, 2020, p.68). The COVID-19 outbreak started as some pneumonia cases of unknown etiology in Wuhan City, Hubei Province of China, on December 31, 2019 (World Health Organization [WHO], 2020). The outbreak became a Public Health Emergency of International Concern (PHEIC) on January 30, 2020, and a 
pandemic on March 11, 2020 (WHO, 2021a). Mirian et al. note: "sore throat, cough, runny nose, fever, tiredness, body aches, and difficulty in breathing" (Mirian et al. 2021, p.2) as symptoms of COVID-19. SARS-CoV-2 has changed severally over time, reproducing Alpha, Beta, Gamma, Delta, and Omicron Variants of Concern (VOCs) of COVID-19 globally (WHO, 2021b; WHO, 2021e). Regarding COVID-19 transmission modes, Akinyemi et al. contribute:

"COVID-19 is mainly transmitted from symptomatic people to others who are in close contact through respiratory droplets, by direct contact with infected individuals, or by contact with contaminated objects and surfaces." (Akinyemi et al., 2020, p.957)

The first case of COVID-19 in sub-Saharan Africa was recorded in Nigeria (Akinyemi et al., 2020, p.958). The index case observed in Italian in Ogun State and diagnosed at a Lagos hospital was confirmed by the Federal Ministry of Health $(\mathrm{FMoH})$ on $27^{\text {th }}$ February 2020 (Nwafor et al., 2020, p.2). An ensuing nationwide spread of the disease had produced 10,162 cases by $31^{\text {st }}$ May 2020 (Nwafor et al., 2020, pp.2-3). A second wave of the pandemic surfaced in Nigeria in early December 2020, causing spike in cases, hospitalizations, and deaths (Partnership for Evidence-Based Response to COVID-19 [PERC], 2021, p.1). As of $14^{\text {th }}$ February 2021, about 55 different lineages of SARSCoV-2 were spreading in Nigeria and confirmed cases had exceeded 150,000 by February 27, 2021 (Akor, 2021; Akor et al., 2021). The detection of the first Delta variant case in Nigeria in a traveler on $8^{\text {th }}$ July 2021 ushered in a third wave characterized by more than two months of sharp surge in cases (Alabi, 2021a; Ileyemi, 2021). Nigeria confirmed six Omicron variant cases and the beginning of a following fourth wave on December 7, 2021 (Alabi, 2021b; Olisah, 2021). Cumulatively, as of $7^{\text {th }}$ December 2021, Nigeria had a total of 214,896 confirmed cases, 207,495 discharged cases with 2,980 deaths (Nigeria Center for Disease Control [NCDC], 2021a).

Response to COVID-19 in Nigeria is guided by science and strengthened by coordination, collaboration, and cooperation involving the government, partners, private sector, and the citizenry (NCDC, 2021b, para.1). And fundamental to the response is Public Health and Social Measures (PHSMs) which the WHO highlights:

"PHSMs include personal protective measures (e.g. physical distancing, avoiding crowded settings, hand hygiene, respiratory etiquette, mask-wearing); environmental measures (e.g. cleaning, disinfection, ventilation); surveillance and response measures (e.g. testing, genetic sequencing, contact tracing, isolation, and quarantine); physical distancing measures (e.g. regulating the number and flow of people attending gatherings, maintaining distance in public or workplaces, domestic movement restrictions); and international travel-related measures." (WHO, 2021c, p.1)

Explicitly, the Coronavirus (COVID-19) Health Protection Regulations 2021 signed into law on $26^{\text {th }}$ January 2021 mandates the full enforcement of PHSMs in Nigeria (Ayitogo, 2021). The NCDC leads surveillance, response measures, popularizes personal protective and environmental measures and supports the multi-sectoral response of the Presidential Steering Committee on COVID-19 (PSCCOVID-19), together with the FMoH, that largely covers physical distancing and international travelrelated measures (Ihekweazu et al., 2021; NCDC, n.d.). Also, actively engaged in critical research and support aspects of response are the National COVID-19 Research Coalition (NCRC) and the Private Sector Coalition against COVID-19 (CACOVID), respectively, among other stakeholders (Ihekweazu et al., 2021). 
Moreover, medical countermeasures aid the response, as the National Primary Health Care Development Agency (NPHCDA) currently leads a four-phased vaccine rollout in Nigeria (Adebowale and Onyeji, 2021; Okunola, 2021). Adebowale (2021) states that the rollout commenced its first phase targeted at frontliners on 5th March 2021 and entered its second phase on $16^{\text {th }}$ August 2021, which Erunke (2021) confirms is targeted at people aged 18 years and above. As of 6th December 2021, 3,811,693 eligible people had been fully vaccinated in Nigeria (NPHCDA, 2021). With the organized efforts noted, it is, however, dismaying to admit that corruption is perceived as a major threat to COVID-19 response in Nigeria, a trend Anyanwu et al. corroborate:

"Nigeria is the most populous black nation in the world, and is one of the largest crude oil producers in the world. However, its healthcare system is dilapidated and weak, due to years of neglect and widespread corruption. As a result, Nigeria is vulnerable to COVID-19, as evidenced by the current geographical distribution of the disease in its population." (Anyanwu et al., 2020, p.1)

"The looting of funds earmarked for the reformation of Nigeria healthcare systems" (Anyanwu et al., 2020, p.2) undermines response by creating health challenges that exacerbate the susceptibility of Nigerians to COVID-19. Some of the challenges are poor funding, weak health system, shortage of healthcare workers, non-remuneration of frontline health workers by state governments and public hospitals, and health sector corruption (Alake, 2021, para.2; Ezeibe et al. 2020, p.1754; Ogbolosingha and Singh, 2020, p.71). These worrisome observations inspire Jenifa on Lockdown, an anti-corruption drama series produced and co-written by Funke Akindele Bello.

Born in Lagos, Nigeria on $24^{\text {th }}$ August 1977, Funke Akindele Bello had her primary, secondary, and tertiary education in the country and has become a popular multi-award-winning Nigerian actress, producer, and script writer whose prosperous career spans over two decades (Bada, 2021; Olumide, 2021). Famous for the stage name Jenifa, Funke Akindele Bello is the Chief Executive Officer of Scene One Production, a content production company that airs its movies, drama series, and shows on television stations and its streaming platform sceneone.tv (ReDahlia, 2018). The entertaining content of the company, including Jenifa on Lockdown, is accessible on its YouTube channel, SceneOne TV, which as of $7^{\text {th }}$ December 2021 had 827,000 subscribers.

Set in Lagos and Aiyetoro town in Ogun State, Nigeria, Jenifa on Lockdown is named after the main character, Jenifa. Predominantly, the characterization of Jenifa explores the social and political contexts of the nine-episode play as an employer, a native of Aiyetoro town governed by a corrupt local government chairman, a politician, a human rights activist, and an anti-corruption advocate to push a public health discourse with an underlying anti-corruption thematic preoccupation aimed at stimulating action against bad governance and promoting healthcare in Nigeria. Central to Jenifa on Lockdown as a critical commentary is the reality of COVID-19 in Nigeria, addressing corruption as a menace to precautionary and control measures in the country, and championing the quest for change.

Notably, Jenifa on Lockdown is plotted after lockdown restrictions that pervaded the experience of the first wave of COVID-19 in Nigeria in 2020. On the outbreak of COVID-19, Nigeria enforced a two-week nationwide lockdown which took immediate effect on $30^{\text {th }}$ March 2020 as a control measure (Ibrahim et al., 2020, p.400). After a three-week extension, a phased easing of the lockdown followed to alleviate its economic consequences on the populace (Nwafor et al., 2020, p.6). The first phase of the lockdown ease spanned May 4 to June 1, 2020, the second June 2 to September 3, 2020, 
and a third commenced on September 4, 2020 (Adebowale, 2020). The third phase elapsed upon the introduction of a fourth phase which Lassa and Njoku (2021) confirm came into force on 11th May 2021.

\section{Relevant Literature}

Language is a medium of linguistic communication that incorporates many mutually intelligible varieties (Nwala and Tamunobelema, 2019, p.10). Stylistics studies the language of literature and divergent styles in language usage (Tariq, 2018, p.46). Otherwise called literary linguistics, stylistics has a scope of study and analysis which transcends literary texts (Burke, 2014, p.1). Extant sociopragmatic theories, including Speech Act Theory (SAT), are contemporary stylistic approaches to drama and performance (Macrae 2014, p.258). Haugh et al. (2021, p.1) define socio-pragmatics which they clarify as an extension of general pragmatics thus:

"[...] the study of users' perception of the contextual factors, including perceived sociocultural norms, underlying the interpretation and performance of communicative acts as (in)appropriate." (Haugh et al., 2021, p.1)

Also, Haugh et al. stress that socio-pragmatics as a merger of pragmatics and sociolinguistics involves "identifying and analyzing evidence for societal norms and how they are subscribed to and contested" (Holmes 2018, p.15 cited in Haugh et al. 2021, p.5). Speech Acts are "acts performed via utterances" (Yule, 1996, p.42 cited in Suresh and Sudhir, 2020, p.2). SAT was propounded in the posthumous publication How to Do Things with Words (1962) of J.L. Austin's lecture series, the book which crystalizes the "use" sense of language (Suresh and Sudhir, 2020, p.2). SAT provides a relevant framework that not only explores the interpretive importance of dramatic conversations but also aids the comprehension of the connection between utterances and interpretation in drama (Macrae, 2014, p.259; Short, 2007 quoted in Macrae, 2014, p.259).

J.R. Searles reviewed SAT in his popular article "A Classification of Illocutionary Acts" (Suresh and Sudhir, 2020, p.4). Quoting Searles (1969, 1975), Macrae (2014, p.259) discriminates five types of Speech Acts, including assertives and representatives, directives, commissives, expressive, and declaratives. The Speech Acts are illocutionary acts classified relative to distinct functions or illocutionary force (Kone, 2020, p.815). Representatives communicate the belief of a speaker(s), assertives constrain a speaker to the truth of the main proposition, and directives spur, or attempt to spur, an addressee to action (Bousfield, 2014, p.121). Commissives bind a speaker to future action, expressives express the emotions and/or attitudes of a speaker(s), and declaratives change others' understandings of reality corresponding to a communicated proposition (Bousfield, 2014, p.122).

Singh and Vodanovich (2017) explain that social media provide platforms for interactions essential to "health promotion, patient education, ... health policies and healthy lifestyle" (Singh and Vodanovich, 2017, p.70). Similarly, the European Center for Disease Prevention and Control (ECDC) adds:

"Social media enhance the speed at which communication is sent and received during public health emergencies or outbreaks, help mobilize community action, facilitate desired behavior changes, allow for a better understanding of public perceptions of issues, and make it easier for users to participate and engage." (ECDC, 2016, p.1) 
Moreover, the significance of the online media as useful anti-corruption tools, especially in the fight against corrupt acts that jeopardize public health, is affirmed by the United Nations Office on Drugs and Crime ([UNODC], 2020, para.1) who stresses the capability of social media to clamor for accountability and transparency from the public domain, particularly by giving information on public sector corruption, exposing corruption to public scrutiny, and challenging impunity. Such information is communicated through analysis, commentary, and advocacy (UNODC, 2020, para.7).

YouTube is a social media platform that offers channels access to a massive potential population from over 2 billion users worldwide (Geyser, 2021). YouTube, the favorite of $63 \%$ of online adults, supports health promotion by facilitating mainly online and impactful stakeholder engagement with priority audiences through health-related videos (Duke et al., 2019; Kakkar, 2020). That way, YouTube supports social media roles in health promotion that according to Stellefson et al. (2020) and Gandolf (2021) include affording patient-provider connection, health consumers' access to timely interaction, authoritative information, aggregated healthcare interests and issues, prospects for wider reach, better efficiency, reduced costs of related communication and advocacy campaigns.

\section{Research Problem and Objectives}

\section{Research Problem}

Several studies have been conducted on the COVID-19 pandemic in Nigeria. Onyeaghala and Olajide (2020) examined managing COVID-19 outbreak in Nigeria in relation to matters arising. Abubakar et al. (2021) explored lessons from the co-production of evidence and policy in Nigeria's COVID-19 response. Okaisabor (2021) investigated challenges, effects, and perceptions of public policies against COVID-19 pandemic in Nigeria. However, the studies were carried out from a non-linguistic perspective. This study aims to do a socio-pragmatic reading of health issues raised about COVID-19 as a public health problem in Nigeria in Jenifa on Lockdown. It seeks to contribute to health uniquely, using dramatic insights within a stylistic perspective that encompasses an effective socio-pragmatic approach. This is the gap this study intends to fill.

\section{Research Objectives}

The objectives of this research are as follows:

1. To identify representational utterances with severe implications for public health used in the dramatic performance;

2. To examine how the identified utterances are applied to establish the reality of COVID-19 and expose corruption as a threat to COVID-19 response;

3. To relate the health crisis to the strife for an effective health system in Nigeria.

\section{Materials and Methods}

The philosophical underpinning for this research was based on the critical theory outlined by Mazouz (2020). It sought to critically examine the reality of political corruption as a menace to COVID-19 response and public health in Nigeria based on health concerns raised in Jenifa on Lockdown. It required a qualitative methodological approach to influence the appropriate collection, analysis, and 
interpretation of characters' utterances in the play to arrive at results that establish the perceived reality and proffer a workable solution. The inductive research approach was adopted for this study as it enabled the achievement of its aim and objectives, applying Searles' model of Speech Act Theory as a conceptual framework. It determined the collection of illustrative data that explored the subject matter and supported its general applicability to the Nigerian experience.

This study adopted a qualitative research strategy that informed an applied research process. The process influenced the collection, analysis, and interpretation of data to depict and address reality in line with the purpose of the study. Also, it shaped the conclusion of the study accordingly. This study deployed the purposive sampling method that patterned a convenient selection of representational primary data from The Virus, The Helper, Devoted Ones, Caught Up, and Caught Up 2 episodes of Jenifa on Lockdown. The primary data included twelve extracts of characters' utterances that comprise critical directives, representatives, declaratives, and commissives. Pertinent secondary data was collected from reports, publications, and updates of the ECDC, FMoH, NCDC, PERC, UNICEF, UNODC, and WHO; journal articles; newspaper reports; web pages and documents. Data was analyzed using a stylistic, discourse analytical approach that fits into the Searles' model and facilitates a socio-pragmatic contextualization of featured illocutionary acts to push responsive public health reforms in Nigeria.

\section{Results and Discussion}

COVID-19 is a public health problem in Nigeria. Response to COVID-19 faces political corruption in the form of embezzlement of budgetary allocations to health with severely complicated outcomes against public health in the country. Such outcomes include the understaffing and underfunding of the health sector, alarming population per health center, lack of isolation centers, non-remuneration of frontline health workers, unethical conduct among health workers, and the discouragement of volunteerism. This study addresses the issues, their outcomes and ultimate health implications as captured in twenty-five illocutionary acts featured in extracted characters' utterances in Jenifa on Lockdown, applying the Searles' model of the Speech Act Theory. Specifically, this study deploys seven directives, fourteen representatives, two declaratives and two commissives to build a radical health narrative that exposes how identified outcomes weaken Nigeria's public health interventions and demands action against corruption to achieve good governance, adequate health financing, a wellequipped and well-supported health workforce in the country. The dramatic activism drives this study on the following basis:

- Awareness creation

- Indicators of corruption

- The importance of preventing corruption

- Social accountability as an anti-corruption strategy 


\section{Awareness Creation}

Jenifa. [...] Remember COVID-19 is real and everyone should protect themselves. ... If you touch a surface, you sanitize your hands if you don't have soap and water. Please, don't touch your nose and mouth. Use your face mask when you go out. (SceneOne TV, 2021a, 03:58)

In the extract above, Jenifa explores the illocutionary force of directives to elicit action from her domestic employees, Laide and Jessica. She performs five directives to spur them to cultivate a healthy lifestyle required to be safe from COVID-19. The first: "Remember COVID-19 is real" initiates an explicit concern for the reality of COVID-19 in Nigeria. The next: "everyone should protect themselves" counsels everyone to necessarily take precautions against the risk of infection. The performative verb "should protect" compels personal adherence to safety measures. Subsequent directives emphasize some advisory measures which the United Nations Children's Fund (UNICEF) tags: "simple hygiene measures" (UNICEF, 2020). The directive: "If you touch a surface, you sanitize your hands if you don't have soap and water" necessitates hand hygiene using a sanitizer or soap and water. The next: "Please, don't touch your nose and mouth" appeals for refrain from touching the nose and mouth indiscriminately. And the last directive: "Use your face mask when you go out" tasks masking up to prevent droplets from the nose or mouth from contaminating surfaces or causing human-to-human transmission, a precaution confirmed by WHO (2021d) as essential to keep oneself and others safe. That way, ignorant Nigerians who the domestic workers epitomize are sensitized to the reality of COVID-19 and mandatory personal safety measures to promote public health amid the pandemic.

\section{Indicators of Corruption}

Chairman. [...] COVID is a blessing; it is a huge blessing. ... This kind of money is what we call embezzlement. (SceneOne TV, 2021b, 05:08).

While conversing with his vice at the beginning of the COVID-19 crisis in Nigeria in the excerpt, the Chairman of Aiyetoro Local Government performs revealing representative acts which communicate a corrupt belief held by culpable political office holders in Nigeria who he represents. Two of them: "COVID is a blessing" and "it is a huge blessing" are perception indicators of corruption. They express the corrupt perception of the COVID-19 pandemic as not just an opportunity but a gigantic opportunity to become enriched with monetary allocations to health meant to finance a response. And the last representative: "This kind of money we are talking about is what we call embezzlement" reflects embezzlement as the form of political corruption the perpetrators commit. Still on corruption, Jenifa utters:

Jenifa. [...] The government provided money for an isolation center, but he squandered it and directed COVID-19 patients to the medical center, and he's yet to pay salaries. (SceneOne TV, 2021b, 44:51)

She performs four representatives which indicate a general perception of reprehensible leaders as grossly insensitive to public health in Nigeria during the COVID-19 crisis. The first: "The government provided money for an isolation center" reiterates the government's financial commitment to response concerning the provision of adequate health facilities. However, the second: "but he squandered it" laments callous embezzlement of allocations. And the remaining two: "directed COVID-19 patients to the medical center" and "he is yet to pay salaries" raise genuine 
concerns about the resultant overburdening of existing health facilities and non-remuneration of frontline health workers, respectively, as governance indicators of corruption. The lack of remuneration has led to frequent strike actions in Nigeria, the latest embarked on by the National Association of Resident Doctors which Ojerinde (2021) confirms commenced on $2^{\text {nd }}$ August 2021 and lasted two months. It has also degenerated into a medical brain drain that Alake (2021) affirms has resulted in a severe staff shortage in healthcare in Nigeria, a major challenge contended in a representative act performed by Nurse Rufus during a conversation with fellow health workers on the appalling situation at the Aiyetoro Medical Center thus: "We don't even have enough health workers" (SceneOne TV, 2021a, 21:00). Substantiating the fallout, Muanya and Onyenucheya report:

"[...] with Nigeria's population at about 200 million, the ratio of doctor per patient remains 1:5,000 as against the World Health Organization's (WHO) recommendation of 1:600, which poses a severe risk on the health of the populace [...]" (Muanya and Onyenucheya, 2021, para.2)

Altogether, these outcomes overwhelm active healthcare workers, subject them to burnout and hardship, and cause demotivation, poor patient-centered care, and increased risk of mortality in Nigeria. Moreover, when Nurse Rufus appeals to Dr. Felix for assistance to tackle a COVID-19 workload at the Medical Center shunned by volunteer nurses, Dr. Felix utters: "They are not volunteering because their salaries are not paid" (SceneOne TV, 2021c, 39:05). His utterance is a representative act which echoes the public conviction that the government's failure to adequately remunerate health workers is responsible for the denial of the short-staffed statutory sector of the much-needed volunteer support to provide care. Such a predicament leaves the susceptible population of Nigeria at the mercy of an acutely undermanned and overstretched health workforce.

Successively, afraid that he might not survive COVID-19 which he contracts during a shady home healthcare service, Nurse Rufus confesses: "I and Joseph who is the Health Records Officer of Aiyetoro Medical Center collaborated with Dr. Felix to steal test kits" (SceneOne TV, 2021e, 11:48). His is a declarative act which changes ignorant understandings of health sector corruption. The admission of guilt for theft of medical testing kits supplies encapsulates the reality of unscrupulous practices erring health workers in Nigeria are involved in. Thereafter, Nurse Rufus adds: "We use them to test rich families". This is another declarative that acknowledges the rich as beneficiaries of the theft, an anomaly that perpetrates health inequity to the detriment of the majority who are poor and vulnerable.

Confronted with the theft allegation, in defense, Dr. Felix utters: "You guys know that our salaries are not being paid" (SceneOne TV, 2021e, 26:12). His utterance is a representative that again signals the lack of remuneration as a governmental failure. In the following representative, he concludes: "This is an opportunity to live well". The act expresses perpetrators' regard for theft as a viable alternative means of improving their living conditions. Both acts expose corruption as the source of financial deprivation which should not justify unethical conduct but unfortunately emerges as a primary cause of shifts in the moral standards of erring health workers in Nigeria who, in turn, violate the principle of justice to make ends meet. In that manner, political corruption is clearly implicated as a major cause of health inequity in Nigeria. 


\section{The Importance of Preventing Corruption}

Jenifa. [...] If corruption dies in our country, the economy will be better like the countries abroad. (SceneOne TV, 2021b, 46:12)

In view of numerous indications of the pernicious influence of corruption on COVID-19 response in Nigeria, Jenifa deploys the directive act above to submit that Nigeria's prospects of developing an economy as advanced as developed economies depend solely on ending corruption. The submission urges consideration for action towards curbing corruption in governance which would enable the efficient use of the nation's resources. Such prudence would establish a successful health system that would aid economic development. The WHO recognizes the act's contribution as it notes: "Economic growth and development depend on a healthy population" (WHO, 2016, p.9). Good governance would guarantee appropriate investment in the Nigerian health system that influences economic growth along other pathways that the WHO avers:

"Targeted investment in health systems, including the health workforce, promotes economic growth along other pathways: economic output, social protection and cohesion, innovation and health security." (WHO, 2016, p.10)

\section{Social Accountability as an Anti-corruption Strategy}

Timini. [...] We can get the people of Aiyetoro to sign a petition against the chairman, which can be sent to the House of Assembly. (SceneOne TV, 2021d, 11:37)

At the climax of political corruption at Aiyetoro, Jenifa seeks the advice of her Personal Assistant, Timini, on what can be done to stem the tide. His response is the directive act above which proposes a social accountability initiative for deliberation. The directive features the performative verb "can" to underscore the ability, right, and the possibility of citizens to develop a common voice and exercise the power of engagement to resist political corruption. Specially, it seeks to motivate citizens to use their democratic capacity to fight corruption and transmit complaints against corrupt leaders freely to the appropriate authority to elicit the required institutional intervention to make them accountable. The proposal substantiates social accountability as an effective anti-corruption measure which Camargo underscores:

"At its core, social accountability involves generating and articulating citizens' voice to elicit enforcement of sanctions when public service provision fails, and to promote answerability of public authorities. Therefore, effective social accountability is made up of three building blocks - voice, enforceability and answerability - which together form a cycle.” (Camargo, 2018, p.4).

Subsequently, a dramatic experimentation of the initiative in Aiyetoro town succeeds. A mobilized public action works out. It is confirmed by a happy youth, Dayo, who utters: "They have petitioned and probed him" (SceneOne TV, 2021e, 37:42). The utterance consists of two representatives: "They have petitioned him" and "They have probed him". The performative verbs "have petitioned" and "have probed" in both acts project a positive notion about the applicability of the anti-corruption mechanisms that social accountability offers to Nigeria. Also, happily, Jenifa reacts: "The chairman thought he was above the law." (SceneOne TV, 2021e, 41:02). Hers is a representative that conveys an appropriate stance which categorically displaces the belief of impunity from the law held by 
corrupt public office holders in Nigeria. The performative verb "thought" exposes their mindset that they are immune from prosecution for every corrupt act they commit. The performative verb "was" strongly alienates the existing systemic mentality from contemporary Nigeria and radically launches an emancipatory projection of a corruption-free Nigeria. Thereupon, Jenifa concludes: "All the corrupt leaders will go down one after the other," and "there will be peace in our country". Both acts are commissives used to commit Nigerians to hope and work towards the eradication of corruption in Nigeria.

\section{Conclusion}

This study concludes that ending corruption will solve all identified health challenges and improve the health system in Nigeria. An enhanced health system would promote public health, respond effectively to present and future health emergencies, and drive economic development. Therefore, this study recommends a bottom-top approach that entails social accountability to achieve answerability, good governance, a successful and sustainable health system in Nigeria. This research endorses the effectiveness of dramatic campaigns on social media in health promotion. Thus, it suggests further linguistic research into critical, dramatic perceptions of health to boost healthcare and wellbeing.

\section{Implications}

The results of this study have both theoretical and practical implications. This study justifies a sociopragmatic reading concerned with how perceived contextual factors determine the appropriateness of the performance and interpretation of acts. It has established how leadership shapes public subscription to appropriate, enlightening health discourse on COVID-19 through speech acts. Also, it demonstrates the functionality of acts in the subscription to, or contestation of depraved sociopolitical norms. It displays the illocutionary force of acts that reproduce and resist the culture of systemic corruption in society to promote public health. These theoretical implications establish the relationship between context and language use, and its potential for driving health-cum-political discourse dramatized on social media to enhance wellbeing. These present practical implications for researchers to focus on further linguistic explorations of dramatic, advocacy campaigns on social media platforms such as YouTube to contribute to health promotion, using the socio-pragmatic approach.

\section{Limitations}

This study has two limitations that impede the generalization of its results. Both are inter-relatedly subjective and geographical and could be useful for future research. The primary data for the study was subjective, as it was collected from an online drama series on YouTube based on the perceived Nigerian experience only. Thus, results obtained cannot be generalized or assumed to depict the reality of any other country. It should be noted that the choice of primary data is informed by its enablement of a sound analysis that largely corresponds to objective academic, expert, and media validations of the Nigerian situation. Further research could consider examining COVID-19 as a public health problem in Nigeria, applying objective data obtained through observation or interviews to achieve a basically empirical analysis and more reliable results. Also, the scope of further linguistic studies should be purposefully inclusive of public health issues in some other African countries. This 
would strengthen research, provide more robust findings and highly engaging insights applicable to the promotion of public health in Africa.

\section{Declaration of Interest Statement}

The author declares that she has no conflict of interests

\section{References}

Abubakar, I., Dalgish, S., Ihekweazu, C., Bolu, O., \& Aliyu, S. (2021). Lessons from co-production of evidence and policy in Nigeria's COVID-19 response. BMJ Global Health, 6(3), 1-6. doi: 10.1136/bmjgh-2020-004793

Adebowale, N. (2020, September 3). COVID-19: Nigeria's third phase of eased lockdown to last four weeks - official. Premium Times, Retrieved from http://www.premiumtimesng.com

Adebowale, N. (2021, August 16). Nigeria to receive more Oxford-AstraZeneca vaccine Monday, flags off second phase of vaccination. Premium Times, Retrieved from http://www.premiumtimesng.com

Adebowale, N., \& Onyeji, E. (2021, May 3). Why Nigeria may not meet its COVID-19 vaccination target. Premium Times, Retrieved from http://www.premiumtimesng.com

Akinyemi, K., Fakorede, C., Anjorin, A., Abegunrin, R., Adunmo, O., Ajoseh, S., \& Akinkunmi, F. (2020). Intrigues and challenges associated with COVID-19 pandemic in Nigeria. Health, 12, 954971. doi: $10.4236 /$ health.2020.128072

Akor. (2021, February 19). 55 COVID-19 variants circulating in Nigeria - NCDC. Daily Trust, Retrieved from http://www.dailytrust.com

Akor, O., Mensah, O., \& Ramoni, R. (2021, February 28). Nigeria: COVID-19 - one year after Nigeria's index case. Daily Trust, Retrieved from http://www.dailytrust.com

Alabi, M. (2021a, July 8). COVID-19: Nigeria records first case of 'most transmissible' Delta variant. Premium Times, Retrieved from http://www.premiumtimesng.com

Alabi, M. (2021b, December 7). UPDATED: COVID-19: Lagos announces the beginning of fourth wave. Premium Times, Retrieved from http://www.premiumtimesng.com

Alake, T. (2021, August 2). Nigerian doctors start strike amid rising coronavirus cases. Bloomberg, Retrieved from http://www.bloomberg.com

Anyanwu, M., Festus, I., Nwobi, O., Jaja, J., \& Oguttu, J. (2020). A perspective on Nigeria's preparedness, response, and challenges to mitigating the spread of COVID-19. Challenges, 11(22) 115. doi: 10.3390/challe11020022

Ayitogo, N. (2021, February 2). COVID-19: IGP orders AIGs, CPs to enforce use of facemasks, others. Premium Times, Retrieved from http://www.premiumtimesng.com

Bada, G. (2021, June 30). Funke Akindele-Bello: The road to fame, fortune. The Nation, Retrieved from http://www.thenationonlineng.net

Bousfield, D. (2014). Stylistics, speech acts and im/politeness theory. In Burke, M. (Ed.), The routledge handbook of stylistics (pp. 118-135). London and New York, OX and NY: Routledge.

Burke, M. (2014). Introduction. In Burke, M. (Ed.), The routledge handbook of stylistics (pp. 1-7). London and New York, OX and NY: Routledge.

Camargo, C. (2018). Harnessing the power of communities against corruption a framework for contextualizing social accountability (U4 Brief). Retrieved from http://www.u4.no/publications/harnessing-the-power-of-communities-against-corruption.pdf 
Duke, C., Yin, J., Zhang, X., Blankenship, E., Akuse, S., Shah, G., ... Fung, H. (2019). Adopting YouTube to promote health: Analysis of state health departments. The Permanente Journal, 23, 1-6. doi: 10.7812/TPP/18-094

Erunke, J. (2021, August 16). COVID-19: FG flags off phase 2 vaccination rollout. Vanguard, Retrieved from http://www.vanguardngr.com

European Center for Disease Prevention and Control. (2016). Social media strategy development a guideline to using social media for public health communication. Retrieved from http://www.ecdc.europa.eu/sites/default/files/media/en/publications/Publications/social-mediastrategy-guide-for-public-health-communication.pdf

Ezeibe, C., Ilo, C., Ezeibe, E., Oguonu, C., Nwankwo, N., Ajaero, C., \& Osadebeh, N. (2020). Political distrust and the spread of COVID-19 in Nigeria. Global Public Health, 15(12), 1753-1766. doi: 10.1080/17441692.2020.1828987

Gandolf, S. (2021). Features, advantages, and benefits of social media in health care. Healthcare success, Retrieved from http://www.healthcaresuccess.com

Geyser, W. (2021, August 4). How to get free YouTube subscribers to grow your channel. Influencer MarketingHub, Retrieved from http://www.influencermarketinghub.com

Haugh, M., Kadar, D., \& Terkourafi, M. (2021). Introduction directions in sociopragmatics. In Haugh, M., Kadar, D., \& Terkourafi, M. (Eds.), The Cambridge handbook of sociopragmatics (pp. 112). New York, NY: Cambridge University Press.

Ibrahim, R., Ajide, K., \& Julius, O. (2020). Easing of lockdown measures in Nigeria: Implications for the healthcare system. Health Policy and Technology, 9, 399-404. doi: 10.1016/j.hlpt.2020.09.004

Ihekweazu, C., Mba, N., Oladejo, J., Abdllahi, Y., Ilori, E., Ibekwe, P., ... Namara, G. (2021, February). One year after: Nigeria's COVID-19 public health response February 2020-January 2021. Retrieved from http://covid19.ncdc.gov.ng/media/files/COVIDResponseMarch1.pdf

Ileyemi, M. (2021, October 4). COVID-19: Third wave eases as Nigeria records 74 new cases. Premium Times, Retrieved from http://www.premiumtimesng.com

Kakkar, G. (2020, January 21). What are the different types of social media? Digital Vidya, Retrieved from http://www.digitalvidya.com

Kone, N. (2020). Speech acts in UN treaties: A pragmatic perspective. Open Journal of Modern Linguistics, 10, 813-827. doi: 0.4236/ojml.2020.106051

Lassa, R., \& Njoku, I. (2021, May 11). COVID-19: Nigerian government reimposes restrictions, modifies measures. Voice of Nigeria, Retrieved from http://www.von.gov.ng

Macrae, A. (2014). Stylistics, drama, and performance. In Burke, M. (Ed.), The routledge handbook of stylistics (pp. 253-267). London and New York, OX and NY: Routledge.

Mazouz, H. (2020, September). Philosophical underpinning of qualitative enquiry. Retrieved from http://www.researchgate.net/publication/344015631_philosophical_underpinning_of_qualitative_enq uiry

Mirian, C., Danjuma, M., \& Amaonyeze, B. (2021). Impact of corona virus disease-2019 (COVID19) pandemic on social lives and interactions of Nigerian citizens. iMedPub Journals, 13(3), 1-9. Retrieved from http://www.archivesofmedicine.com

Muanya, C., \& Onyenucheya, A. (2021, February 4). Bridging doctor-patient ratio gap to boost access to healthcare delivery in Nigeria. The Guardian, Retrieved from http://www.guardian.ng

National Primary Health Care Development Agency. (2021). In Facebook [Facebook page]. Retrieved December 8, 2021, from http://web.facebook.com/NPHCDA

Nigeria Center for Disease Control. (NCDC, 2021a, October 4). COVID-19 Nigeria highlights. Retrieved from http://covid19.ncdc.gov.ng 
NCDC. (2021b, February 27). One year of COVID-19 response in Nigeria. Retrieved from http://ncdc.gov.ng/news/item/324/?t=one-year-of-covid-19-response-in-nigeria

NCDC. (n.d.). Public health advisory on COVID-19 Overview. Retrieved from http://covid19.ncdc.gov.ng/advisory

Nwafor, C., Ochu, C., Elimian, K., Oladejo, J., Ilori, E., Umeokonkwo, C., ... Ihekweazu, C. (2020). Nigeria's public health response to the COVID-19 pandemic: January to May 2020. Journal of Global Health, 10(2), 1-9. doi: 10.7189/jogh.10.020399

Nwala, M., \& Tamunobelema, I. (2019). The social media and language use: The case of Facebook. Advances in Language and Literary Studies, 10(4), 9-13. Retrieved from https://www.journals.aiac.org.au

Ogbolosingha, A., \& Singh, A. (2020). COVID-19 pandemic: Review of impediments to public health measures in Sub-Saharan Africa. American Journal of Preventive Medicine and Public Health, 6(3), 68-75. doi: 10.5455/ajpmph.202005120220014

Ojerinde, D. (2021, October 4). Resident doctors call off strike, to resume Wednesday. Punch, Retrieved from https://www.punchng.com

Okaisabor, J.O. (2021). Public policies against COVID-19 pandemic in Nigeria: Challenges, effects, and perceptions. Journal of Public Administration and Social Welfare Research, 6(1), 16-29. Retrieved from http://www.iiardpub.org

Okunola, A. (2021, April 13). 6 things to know about how Nigeria is distributing the COVID-19 vaccine. Global Citizen, Retrieved from http://www.globalcitizen.org

Olisah, C. (2021, December 7). Omicron: NCDC confirm detection of 3 additional cases in Nigeria, brings total to 6. Nairametrics, Retrieved from http://www.nairametrics.com

Olumide, J. (2021, July 23). Funke Akindele net worth, biography, and movies. Creebhills, Retrieved from http://www.creebhills.com

Onyeaghala, A., \& Olajide, I. (2020). Managing COVID-19 outbreak in Nigeria: Matters arising. Clin Chem Lab, 58(10), 1645-1650. doi: 10.1515/cclm-2020-0748

Partnership for Evidence-Based Response to COVID-19. (2021). Finding the balance: Public health and social measures in Nigeria. Retrieved from http://preventepidemics.org/wpcontent/uploads/2021/03/nigeria_en_20210323_1721.pdf

ReDahlia. (2018). Funke Akindele - Biography and business life of Funke Akindele. Retrieved from http://www.entrepreneurs.ng/funke-akindele/

SceneOne TV. (2021a, May 13). The Virus. [Video file]. Retrieved from https://www.youtube.com/watch?v=D0AZWih-AM4

SceneOne TV. (2021b, May 20). The Helper. [Video file]. Retrieved from https://www.youtube.com/watch?v=1HORUIr9vzE

SceneOne TV. (2021c, June 3). Devoted Ones. [Video file]. Retrieved from https://www.youtube.com/watch?v=tdArHyQQARg

SceneOne TV. (2021d, July 1). Caught Up. [Video file]. Retrieved from https://www.youtube.com/watch?v=pkPiVrObB10

SceneOne TV. (2021e, July 8). Caught Up 2. [Video file]. Retrieved from https://www.youtube.com/watch?v=mnnflinTFX0

Singh, T., \& Vodanovich, S. (2017). Health promotion on social media. International Journal of Management and Applied Science, 3(3), pp. 70-75. Retrieved from http://iraj.in

Stellefson, M., Paige, S., Chaney, B., \& Chaney, J. (2020). Evolving role of social media in health promotion: Updated responsibilities for health education specialists. International Journal of Environmental Research and Public Health, 17(1153). doi: 10.3390/ijerph1704115 
Suresh, B., \& Sudhir, M. (2020, August 3-4). A speech act theory: A comparative study. Proceedings of the International Conference on Multidisciplinary Research, Mumbai, MS, India. Retrieved from https://www.researchgate.net/profile/Sudhir-

Mathpati/publication/343820392_A_Speech_Act_Theory_A_Comprehensive_Study/links/5f428d519 2851cd3021fd822/A-Speech-Act-Theory-A-Comprehensive-Study.pdf

Tariq, M. (2018). Style, stylistics, and stylistic analysis: A re-evaluation of the modern-day rhetorics of literary discourse. International Journal of English Research, 4(2), 46-50. Retrieved from https://www.researchgate.net

United Nations Children's Fund. (2020, April 13). Cleaning and hygiene tips to help keep the COVID-19 virus out of your home. Retrieved from http://www.unicef.org/mena/stories/cleaning-andhygiene-tips-help-keep-covid-19-virus-out-your-home

United Nations Office on Drugs and Crime. (2020). The role of the media in fighting corruption. Retrieved from http://www.unodc.org/e4j/anti-corruption/module-10/key-issues/the-role-of-themedia-in-fighting-corruption.html

World Health Organization. (WHO, 2016). Working for health and growth: Investing in the health workforce. Retrieved from http://apps.who.int/iris/bitstream/handle/10665/250047/9789241511308eng.pdf

WHO. (2020, January 20). Novel coronavirus (2019-nCov) situation report - 1. Retrieved from http://www.who.int/docs/default-source/coronaviruse/situation-reports/20200121-sitrep-1-2019ncov.pdf

WHO. (2021a, April 16). The coronavirus disease 2019 (COVID-19) strategic preparedness and response plan for the WHO African region 1 February 2021 - 31 January 2022. Retrieved from https://www.afro.who.int/sites/default/files/2021-04/WHO\%20AFR\%20Covid19\%202021\%20SRP_Final_16042021.pdf

WHO. (2021b). Tracking Sars-Cov-2 variants. Retrieved from http://www.who.int/en/activities/tracking-SARS-CoV-2-variants/

WHO. (2021c, June 14). Considerations for implementing and adjusting public health and social measures in the context of COVID-19. Retrieved from http://apps.who.int/iris/bitstream/handle/10665/341811/WHO-2019-nCoV-Adjusting-PH-measures2021.1-eng.pdf?sequence $=1 \&$ isAllowed $=y$

WHO. (2021d, October 1). Coronavirus disease (COVID-19) advice for the public. Retrieved from http://www.who.int/emergencies/diseases/novel-coronavirus-2019/advice-for-public

WHO. (2021e, November 26). Classification of omicron (B.1.1.529): SARS-CoV-2 variant of concern. Retrieved from http://www.who.int/news/item/26-11-2021-classification-of-omicron(b.1.1.529)-sars-cov-2-variant-of-concern 